\title{
Female Entrepreneurial Capacity in China: A Comparative Study of Two Periods
}

\author{
Farhana Firoz ${ }^{1}$ \\ ${ }^{1}$ School of Business \& Economics, North South University, Dhaka, Bangladesh. \\ Correspondence: Farhana Firoz, School of Business \& Economics, North South University, Dhaka, Bangladesh.
}

Received: June 12, 2015

Accepted: June 26, 2015

Available online: July 21, 2015

doi:10.11114/ijsss.v3i5.879

URL: http://dx.doi.org/10.11114/ijsss.v3i5.879

\begin{abstract}
This is a comparative study of women in China in their career choices as entrepreneurs based on self-efficacy theory, in two periods, 2002 and 2010. Existing literatures not only suggest, self-efficacy is an essential factor in career choices but also suggest that it varies considerably in genders. In addition, self-efficacy is developed through social persuasion which ultimately affects people's career choice. Literatures also suggest that China is a country, where women face much social pressure and barriers .So study assumes, Chinese women's self-efficacy is not that much due to social suppression and aims to see whether with time there has been any increase in self-efficacy in choosing their career as entrepreneurship.

Individual data of Global Entrepreneurs Monitor (GEM) and self-efficacy theory are used to test self-efficacy and entrepreneurial intentions, to interpret women's changing orientations towards their career as entrepreneurs compared to men, in 2002 and 2010 . The findings of the study have been drawn based on three propositions to check self-efficacy. Each proposition findings are compared among genders for the periods 2002 and 2010 to understand the change in gap, as China progressed. The results suggest, in 2010, though Chinese men are more engaged in entrepreneurship compared to women, but the gap in genders in their self-efficacy \& career self -efficacy is seen to narrow in 2010 than in 2002 . The findings of the research will help in recognizing the importance of the factor self-efficacy and its importance in women's career choice.
\end{abstract}

Keywords: GEM, Self-efficacy, Career self-efficacy

\section{Introduction}

Entrepreneurship is a career which postulates proper opportunity for women worldwide because it gives flexibility, more financial freedom thus better position in the society, change and innovation. And according to UNIDO (1995), this potential has been realized only in optimal way in most transitional economies and developing countries because a large number of contribution of women goes unnoticed in the informal sector and is not counted in national accounts (UNIDO,1995). Several varieties of constraints are there on women which blocks women from upgrading their production ability in a continuous manner. These barriers can be poor access to market information, lack of knowledge in technology and finance, poor linkages with support services and an unfavorable policy and regulatory environment. These constraints are further amplified by the need to compete in an aggressive business environment with rapid technological changes and the globalization of production, trade and financial flows (UNIDO, 2001). Many of these constraints have impacts on both men and women but for women these constraints are much more bigger because of discriminatory socio-cultural values and traditions which are deeply rooted. In many cases, women are unable to benefit from services, and must struggle to overcome discriminations in business environment (UNIDO, 2001).These cases become more clear in country based study, as because country based study on women entrepreneurs can give an important insight on a particular country's socio-economical development, also existing literature shows women entrepreneurs are the building blocks of a society.

This study provides an analysis of the self-efficacy theory in career choice as entrepreneurs of women in China. In doing so, the study aims to further build on the application of the term 'self-efficacy' and how it varies in genders that leads to their ultimate career choice to be an entrepreneur by emphasizing the role of women in continuous changing society of China. It is suggested that a person's intention and ability to engage in certain activities is affected by self-efficacy, that is, the extent to which one has confidence in his or her own capabilities (e.g. Bandura , 1978 ; Boyd 
and Vozikis , 1994) and so it is a very important concept to understand (Litt, 1988),. There are several literature on self-efficacy and how it varies by gender and its significance in career choices(e.g. Bandura,1977; Bandura et.al., 2001; Kickul ,et al. 2004; Scherer,et.al.1989; Hollenbeck and Hall, 2004; Lent and Hackett,1987 ; Nevill \& Schleckler,1988) and there is a developing literature on the position of women in the Chinese labour market and the factors that influence their progress (e.g. Cooke, 2003, 2010; Leung, 2002 ; Maurer-Fazio et.al., 2011), but no literature is found on Chinese women's entrepreneurial intensions based on self-efficacy theory. As a consequence, there is a limited understanding of how best to support women's role in entrepreneurship in China and of the applicability of self-efficacy theory in understanding and informing this process of women's progress in the society. This gap in the literature also leads to lack of enough knowledge about how Chinese women entrepreneurs understand their careers, and how they respond to the opportunities and barriers that they face.

China has been pursued sweeping economic changes since 1978, in an officially sponsored transition from a Stalinist centrally planned economy to a socialist market economy (White et al. 1996). The need to curb the magnificentpower of the Leninist state and change the balance of power between state and economy, state and society were the highlights among the Chinese reformers (White et al. 1996). In practice, China is facing new socio-economic forces, shifting power in their direction, and the possibility of political transformation due to its economic reforms. These reforms have set a continuous process of potentially fundamental social and institutional change in China (White at al.1996). In midst of these reforms, how Chinese women's position changed in terms of their self-confidence in building their career can be an interesting area to study.

This study's analysis is rooted in the change in self-efficacy differences in genders to be entrepreneurs in context of changing culture of China. Relatively little is known about the self-efficacy towards career choices in China, like, choosing entrepreneurship as career in women mainly. The study draw discussion on a sample from China based on the Global Entrepreneurship Monitor's (GEM) individual adult population secondary data of 2002 and 2010, on China.This country provides an interesting setting in which to do a comparative study of entrepreneur start-up activities in men and women in two periods because of the fact that this region is having transitional economy and currently playing significant role in the economy development of Asia Pacific \& South Asian region according to GEM reports 2002 \& 2010 . In addition, the literature reveals that there have been noticeable changes in the socio-psycho-cultural and economic norms in this country and so whether these changes have helped women's condition to improve has been an interesting fact to explore.

To find the effect of self-efficacy in women leading them to choose career as entrepreneurs, and how self - efficacy changed in women in 2010 from 2002, a comparative analysis is done for the two years. To do this, the study first tested significance of difference in perception of self-efficacy to be entrepreneurs in genders with respect of skill, knowledge, experience and fear of failure and compared the results in two periods. Next, for the years 2002 and 2010, significance of self-efficacy as a factor of career choice is tested among genders by taking entrepreneurial activities and future intentions to be entrepreneurs into consideration and a comparison for the two periods is made. Followed by, analysis of significance of entrepreneurial career self-efficacy in traditional and non-traditional careers among genders is tested by taking their current entrepreneurial intentions, intentions of ownership of business and entrepreneurial endeavours under current employment into consideration and a comparison for the two periods is done. Finally, the findings are analysed and explained in realm of transitional Chinese society and self-efficacy theory, which will be useful for future research and policy developmentto developcareer orientations of Chinese women as entrepreneurs that will be appropriate for context of China.

But before the analysis, the study starts by drawing a socio-demographic review of the position of women and women entrepreneurs in the society of China and the changing cultural. This is so, because culture has immense impacts on self-efficacy (Bandura 1977, 1986), which in turn will have influence on women's career. This is followed by reviewing of literature on self-efficacy theory, its significance in career choice and variation of career self-efficacy in genders, which provided the context and link for the analysis and interpretation of findings that follow.

\subsection{Importance of Women Entrepreneurs and Women's Position in China}

Quite a significant role is played by women entrepreneurs worldwide. It is a fact that women entrepreneurs are important building blocks of an economy and they are the drive for growth in the economy of a country (Minniti et al. 2005).There is also the fact that new ventures / businesses are basic components of the advancement of an economy and this is agreed by (Acs, Arenius, Hay, \& Minniti, 2005).Since, women entrepreneurs and new ventures are so important for a country's economy, it is very important that we should know what pulls women behind than their male counterparts. If these factors are studied and improved than women human capital can be used properly in any nation.

General statistics shows, in Africa, Asia, Eastern Europe, and Latin America women entrepreneurship is vastly increasing and in advanced economies, women own 25\% of all businesses (Estes, 1999; Jalbert, 2000). According to 
Women-Owned Businesses (2004), 6.7 million privately held majorities women-owned businesses account for $\$ 1.19$ trillion in sales and employ 9.8 million people, and this is only alone in United States. So, these statistics shows the acceleration rate of women-owned businesses to be impressive. These data signifies the value of studying women's entrepreneurship, and is a good proof that scholars and researchers are paying more attention to the field of women entrepreneurship.

In People's Republic of China, private business is a fairly new area of opportunity for both women and men. There was practically no existence of private businesses until the reforms of the 1980s and it had not been that long an amendment to the Chinese Constitution in 1988 legalized private business activities (Lu and Zhimin, 1997). From the beginning of that time period private business activities were first seen as tolerance but when it was realized that businesses created jobs and supplied goods \& services which were scarce, later private businesses are encouraged (Lu and Zhimin, 1997). But to understand entrepreneurial self-efficacy among Chinese women, it is very essential to understand the position of women in Chinese society in the last few decades.

Women's equal rights in all aspects of life, for example - equal rights in the work place, including equal pay to men, inheritance of land and property, in initiating divorce and claiming their children, right to vote and equal access to education were guaranteed in China by the '1982Constitution of the People's Republic of China . China started to reform with the slogan of Maoistt, 'women hold up half the sky' (Kitching and Woldie, 2004). Statistics showed in the study of Kitching and Woldie (2004), that there were 400 million women in China aged 15 plus years, 300 million women were economically active and two thirds urban and three fourths rural women engage in work outside the home , $44 \%$ agricultural workers comprised of women. In 1990, statistics of Chinese women showed, $45 \%$ of professional and technical personnel were female, this statistic was up from 38\% in 1982 (Kitching and Woldie, 2004) ; 11\% were females among heads of authorities and government organisations, business organisation and institution, and this was $10 \%$ in 1982 (Hall,1997); Jobs which were unimaginable for females before the reform for example - secretary, interpreter, translator, businesswoman and tour guide were becoming new possibilities and the top dream jobs for Chinese women (Hall, 1997). In rural areas of China, out of a million self-employed people, engaging in commerce and service trades, two-thirds of them were women (Xinhua, 2000). In 1990, according to China Women's News, 4.6 million rural women were running businesses, that is, one - third of all rural businesses were women owned , this was a big jump in statistics of women entrepreneurs from 1980 (Kitching and Woldie, 2004). But there is a big gap in reality and the statistics discussed so far. Though China started to reform its society and conditions of women improved from 80 s, but not many women involvement in professional jobs could be seen in China till early $21^{\text {st }}$ century.

Though equal opportunity was established through the 1982 Constitution of the People's Republic of China and the Communist government was committed to support gender equality (Loscocco\& Bose, 1998) with males and females regarded as equal contributors to production, but traditional and cultural aspectshindered and pulled back women from taking participation in the economy (Summerfield,1994). With the economic reforms as traditional institutions received more prominence, the traditional attitudes about the inferiority of women that had been repressed to some extent, resurfaced again. This could be evidenced in various job advertisements with signs that the advertised job was only for men, stories of female infanticide, articles in the press that claimed that women should prove that they were as capable as men otherwise they should go back to the kitchen (Summerfield,1994).

Patriarchal society could be another main reason why women were not seen to practice their career freedom in previous studies. A patriarchal society can be defined as one where women are subject to oppression, exploitation (Walby, 1989) and powerful gendered ideologies (Granrose, 2007; Ebrey, 2003).And so men are more in charge of outside work than women, who are more into domestic work(Kitching and Woldie 2004).China is not only a patriarchal society but also a very strongly collectivist society, that is, individual priority is sacrificed over group priority(Yang, 1988; Kim \& Markus, 1999; Ho\& Chiu, 1994; Triandis, 1995; Yu \& Yang, 1994). This has a great affect within families, in a form of family collectivism, with men being head of the family. Husband and his family's welfare are priorities under the doctrines of collectivist society (Yu \& Yang, 1994, Liu et al. 2010) rather than a women's career(Granrose, 2007), where women is seen to be giving support to their husband by involving themselves in domestic chores and bearing and raising children.

In addition, to the social factors there is also an important factor, which is known as self-efficacy, which is very essential to understand if we are to explain women's career choice in China, in terms of their social position . Self-efficacy, in general, refers to self-confidence that the person has about the required skills, knowledge and experience to succeed in an activity (Bandura,1977), for example - new venture or any activity . And confidence needed for entrepreneurial endeavours is known as entrepreneurial self-efficacy (McGee et al. 2009). Interestingly, it has been found from work of Kickul, et al. (2004) that entrepreneurial self-efficacy differs by gender. For example- they found entrepreneurial self-efficacy were weaker in teenage boys than in teen age girls. For teen girls, it appeared that their perceptions that they had the abilities or skills to succeed as entrepreneurs were simply more important in considering future career options than for boys. 
So from these discussion, it can be said regarding Chinese women, that not only their education but also other factors, like gender inequalities in careers and stereotyped role in the society would have impact on their self-efficacy and ultimately in their career choice. In a patriarchal society, such as China, occupations with lower status and lower position were compatible with women's inferior self-concepts that leads to lower self-efficacy, and their views about accessibility (Greene and Stitt-Gohdes, 1997). This view of patriarchal society can be much explained by its views towards non- traditional career for women like- entrepreneurship. For example-Zunker (1994) stated "the woman who gives her career development equal status with her husband's will find acceptance of her role personally challenging, with little support from many men and women" (p. 341).

More discussion on self-efficacy, its importance in choosing carrier and how career self-efficacy differs in genders are essential to draw propositions on Chinese women's self-efficacy in entrepreneurship field. And this is done in the following sections.

\subsection{Background ofSelf-Efficacy}

Self-efficacy is central to intentions towards entrepreneurship and also self-efficacy predicts opportunity recognition (Scherer, et. al., 1989). To understand entrepreneurial intentions, it is essential to understand the background of self-efficacy.

Social learning theory of Bandura (1977) gave rise to the term 'self-efficacy' and it referred mainly to a person's self-belief of his or her capability to take or perform a task. In his original work, Bandura (1977) defined self-efficacy expectations, asone's own belief about his/ her capabilities to perform an action or execute a behaviour successfully. In realm of this, Bandura hypothesized efficacy expectations would help to determine initiation of a particular behaviour, expended effort, how long the persuasion would stay when faced with obstacles and non- favourable experiences. Self-efficacy is not biologically obtained but could be acquired gradually through the development of a person's complex cognitive, social, linguistic, and/or physical skills that were obtained through experience (Bandura, 1982; Gist, 1987).

Bandura (1986), in his study, hypothesized efficacy expectations to be acquired in four ways, which were1) Performance accomplishments2) vicarious experience and this includes observational learning through modelling 3) verbal persuasion and 4) individual's physiological status. Andhe assumed self-efficacy vary along three dimensions which were 1) level2) strength, and 3) generality. Here 'level' is referredto as one's feeling about what he or she is capable of doing; 'Strength' is referred to one's confidence about his or her capability ; 'Generality' is referred to number of situations in which one believed they had necessary efficacies. Therefore, the acquired skills through past achievements strengthens self-efficacy and contributes to higher motivation for future performance (Herron and Sapienza,1992).This view was also suggested by Wood \& Bandura (1989) ; Lent \&Hackett (1987),that through experience individuals could acquire or develop self -efficacy in an efficient way and this may act positively in future performance. In addition to this, people may evaluate of their own capabilities by comparing themselves to others by observational learning of an individual who had been estimated with relevant skills that would be required to attain same outcome, and this may affect self-efficacy (Gist \& Mitchell, 1992). Another way to improve self-efficacy was through the social persuasion. Receiving favourable feedback \& attainable encouragements about task performance may likely results ingreater effort (Gist, 1987; Wood \& Bandura, 1989).All these concepts together, when self-efficacy is assumed as a key preceding factor to new venture intentions, it is called as entrepreneurship self-efficacy (Boyd \& Vozikis, 1994; Chen et al. 1998; Krueger \& Brazeal, 1994).

From the literature of position of Chinese women and self-efficacy, it can be expected that culture have immense impacts on women's career, which may in turn affect women's experience, skill and knowledge through which individuals can acquire self -efficacy . Also, perception of negative factors, like, lack of social persuasion and fear of failure may hamper self-efficacy .Hence, Chinese women would show less self-efficacy for their social position and this could be reflected in terms of their less perception of their skills, experience and knowledge compared to men. In addition, Chinese women's social position would lead them to have more fear of failure and less self-efficacy compared to men. But women's self-efficacy is expected to increase with the changes in socio-economy changes of China. These assumptions guided to suggest this study's first proposition :

P1: It is suggested that women in China, would be less likely to have perceived knowledge, skill, experience to be an entrepreneur and more perceived fear of failure than men but however these differences in genders would be expected to be narrower in 2010 than in 2002, due to socio -economy changes in China.

\subsection{Self-Efficacy As a factor for Career Choice}

The purpose of the following discussion is to further explain the potential contributions of self-efficacy theory for career choice. This is to increase understanding of women's career choice as entrepreneurs in China. 
In the beginning of $21^{\text {st }}$ century, self-efficacy has been described as one of the variety of socio cognitive influences on the career choices of children by Bandura et al. (2001) and the study found that academic self-efficacy had a very strong influence. Also, in career theory literature, concept of self-efficacy has been used rigorously. It gave logic behind chosen career options, career preferences or desireand important of all ultimate career oriented action (Betz and Hackett, 1981, 1983; Eccles, 1994; Hackett and Betz, 1981).Interestingly, gender could also be a likely factor that may affect innovative attitude towards business establishment. Harris and Gibson (2008) reported that there had been a significant difference between male and female business students in their need for innovation in business.

Bandura $(1977,1986)$ recognizes that enactive performance was the most powerful source of efficacy information; thus, exposure to sex-typed activities may result in differential skill acquisition and, consequently, gender differences in self-efficacy judgments for traditionally female or traditionally male career competencies. Therefore, these findings suggest social differences between men and women may be a causal factor that influence underutilization of women of their career talents (Hackett and Betz,1981), and could be one of the reasons why there were not many women in many careers, like- entrepreneurship, which was traditionally male dominated in China .

From these literatures, it can be said that self-efficacy helps to choose career, and those individuals who have high entrepreneurial self-efficacy will choose entrepreneurial career as a preference. Due to prominence of stereotyping of gender roles in China, women may have less entrepreneurial self-efficacy. Thereby, they would be less involved in entrepreneurial activities and would show less entrepreneurial expectations than men. But situation of women and their self-efficacy towards career choice may improve with changes in socio-economy factors of China. So the next proposition is:

P2 : It is suggested that women in China were less involved in activities in past twelve months that would help to start a new business and they had less expectation than men to start a new business alone or with others, including any type of self-employment within the next three years, however these differences between genders would be expected to be narrower in 2010 than in 2002, due to socio-economy changes in China.

\subsection{Gender and Career Self-Efficacy}

Since China is a patriarchal society (Yu and Zhu, 2000 as cited in Kitching and Woldie,2004), gender stereotyped career are more profoundly present. This fact can form a good argument of career self-efficacy of womenin China regarding entrepreneurship.

In a major review of the career self-efficacy literature name of Lent and Hackett (1987) ; Nevill\&Schleckler,(1988) were mentioned, whose research findings have provided support for the argument that career choice is largely and significantly depends on self-efficacy and self-efficacy differed by genders in traditional and non-traditional careers. This aggregate view was supported by research evidence that women were most likely to have lower expectations than men for success in a wide range of occupations (Eccles, 1994). Therefore, it was not surprising that in women there was measurable or rather significant lower levels of self-efficacy had been found in careers which were historically perceived as non -traditional (Bandura et al. 2001; Betz \& Hackett, 1981; Scherer, et al.1990), for example -entrepreneurship.

In China, inequality among genders and patriarchal society's norms created career choice to besegregated according to gender, therefore, it is less expected that women undersuppression would put much attention on their entrepreneurial opportunities and possibilities. In spite, even if they had necessary skills and capabilities to be in the area of entrepreneurial profession, they would tend to hide their entrepreneurial intension. On the basis ofthe gender and self-efficacyliterature, the assumption is, women of China would show less entrepreneurial self-efficacy because of gender inequality and social issues. Therefore, it is expected they would not demonstrate any entrepreneurial intentionality, or behaviour to tackle challenging situations of risk and uncertainty which would characterizes them as entrepreneurs. However, situation of women and their self-efficacy towards career choice may improve with changes in gender inequalities in China. And this may happen with the socio-economy changes in China. This is reflected in the third proposition :

P3 : It is suggested that women in China would have less intention than men, in trying to start new business alone or with others, including any self-employment or selling any goods or services to others and therefore women would have less intention than men, of owning all, part or none of the business. Also, women in China should have less intention than in men, in trying to starting new business, or new venture for the employer as part of their normal work but however these differences in genders is expected to be narrower in 2010 than in 2002, due to socio-economy changes in China. 


\section{Method}

\subsection{Sample}

In this study, the data set which has been used was adult population individual-level survey data (APS)of $2002 \& 2010$ from the Global Entrepreneurship Monitor (GEM) ${ }^{1}$.

In China, a standardized survey was administered by GEMon a representative sample, i.e - the sample reflected the general acclaim for data ; miniature of the population ; coverage of the population ( Kruskal and Mosteller, 1979). Sample consisted of more than 2,000 adults (18-64 years old) in both the years of 2002 and 2010.The surveys were conducted by telephone or face-to-face between May and August in the national language(s) and facilitated by a translation and back-translation of questions.

\subsection{Procedures and Variables}

From the data set of GEM, amongst numerous countries, only data of China was selected by 'select case' using SPSS .Chi-square test was run, for each year 2002 and 2010 separately, to check the association and significance of 'genders' and each variable, for example- to test the first proposition (P1) about self-efficacy in females and males through perceived knowledge, skill, experience and fear of failure, variables chosen from GEM data for China were-

a. Do you have skill, knowledge\& experience?

$b$. Would fear of failure would prevent you from starting a business ?

Each of these two variables were tested against gender for 2002 and 2010 separately to check the association and significance. This procedure was repeated to check second proposition (P2), that is, self- efficacy as factor for career choice in females and males, and variables chosen from GEM data for China were -

c. Over the past twelve months have you done anything to help start a new business?

d. Are you, alone or with others, expecting to start a new business, including any type of self-employment, within the next three years?

Chi-square was done with each of the above variables against 'gender' for the year 2002 and 2010 separately and association along with significance was checked. To check the third proposition (P3), to check career self-efficacy of males and females in China, three variables were chosen from GEM data for China were-

e. Are you, alone or with others, currently trying to start a new business, including any self-employment or selling any goods or services to others?

$f$. Will you personally own all, part, or none of this business?

g. Are you, alone or with others, currently trying to start a new business or a new venture for your employer as part of your normal work?

At the time of the interview, in both the periods, respondents were asked whether they were alone or with others, trying to start a business, including any self-employment or the sale of goods or services to others. Respondents who answered affirmatively were then asked if they would personally own all, part, or none of this business. This additional question was used to separate those who were truly committed to a new venture from those thinking about but not yet committed to it. Asking respondents whether they were alone or with others, currently trying to start a new business or a new venture for their employer as part of their normal work, may help to recognize managers/ non-managerial employees working for their employers who had self-confidence to work as an entrepreneur and showed courage to gain some entrepreneurial experience which may help in their future entrepreneurial endeavour. A chi- square test was done with each of these variables against gender in each year of 2002 and 2010 to check association and significance.

\section{Results}

In this section, the analysis of the findings are presented. First, the section starts with the descriptive analysis of the samples of the two years. followed by the findings of the propositions.

\footnotetext{
${ }^{1}$ See http://www.gemconsortium.org for more details.
} 
Table 1. Descriptive Statistics for the respondents for the year 2002.

\begin{tabular}{lll}
\hline Gender & Male & Female \\
\hline $\begin{array}{l}\text { Total number of respondents } \\
\text { (n) } \%\end{array}$ & $(996) 48.5$ & $(1085) 51.5$ \\
Ave. age & & 40.28 \\
Age range & 40.13 & \\
\hline
\end{tabular}

Table1,shows sample descriptive statistics of 2002.Total of 2,081 people were in the sample. This consisted of $48.5 \%$ of men and $51.5 \%$ ofwomen with average age of 40.13 years and 40.28 years respectively. The sample consists of people 18 to 64 years.

Table 2 . Descriptive Statistics for the respondents for the year 2010.

\begin{tabular}{lll}
\hline Gender & Male & Female \\
\hline Total number of respondents & $1649(44.8 \%)$ & $2028(55.2 \%)$ \\
$(\mathrm{n}) \%$ & &
\end{tabular}

\begin{tabular}{lr} 
Ave. age & 39.89 \\
Age range & $18-64$ \\
\hline
\end{tabular}

Table-2, shows sample descriptive statistics of 2010. Total of 3,677 people were in the sample. This consisted of $44.8 \%$ of men and $55.2 \%$ of women with average age of 39.89 years and38.5 years respectively. Like the age range in sample of 2002, sample of 2010 also consisted of people with an age range of 18 to 64 years.

P1 : It is suggested that women in China, would be less likely to have perceived knowledge, skill, experience to be an entrepreneur and more perceived fear of failure than men but however these differences in genders would be expected to be narrower in 2010 than in 2002, due to socio -economy changes in China.

a. Do you have the knowledge, skill and experience required to start a new business?

Table 3. Gender and the variable, Do you have skill, knowledge\& experience ?

\begin{tabular}{|c|c|c|}
\hline \multicolumn{3}{|c|}{ Year 2002} \\
\hline & \multicolumn{2}{|c|}{ Gender } \\
\hline & Male & Female \\
\hline No & 512 & 739 \\
\hline $\begin{array}{l}\% \text { within } \\
\text { Variables }\end{array}$ & 40.9 & 59.1 \\
\hline Yes & 446 & 286 \\
\hline $\begin{array}{l}\% \text { within } \\
\text { Variables }\end{array}$ & 60.9 & 39.1 \\
\hline \multicolumn{3}{|l|}{$\mathrm{n}=1983$} \\
\hline \multicolumn{3}{|l|}{$\begin{array}{l}\chi 2=(d f 1,1982)=73.984^{* * *} \\
* * * p<0.001\end{array}$} \\
\hline \multicolumn{3}{|c|}{ Year 2010} \\
\hline & \multicolumn{2}{|c|}{ Gender } \\
\hline & Male & Female \\
\hline No & 759 & 1182 \\
\hline $\begin{array}{l}\% \text { within } \\
\text { Variables }\end{array}$ & 39.1 & 60.9 \\
\hline Yes & 726 & 647 \\
\hline $\begin{array}{l}\% \text { within } \\
\text { Variables }\end{array}$ & 52.9 & 47.1 \\
\hline \multicolumn{3}{|l|}{$\mathrm{n}=3314$} \\
\hline \multicolumn{3}{|l|}{$\begin{array}{l}\chi 2=(d f 1,3313)=61.686^{* * *} \\
* * * \mathrm{p}<0.001\end{array}$} \\
\hline
\end{tabular}


$=61.686, \mathrm{df}=1, \mathrm{p}<0.001$ respectively). The suggested proposition holds and there was enough evidence to suggest that being female was associated to having less perception of knowledge, skill and experience.

Due to continuous economic and social reforms in China, women's condition as entrepreneurs and their self-efficacy were expected to improve in 2010 than in 2002 .This could be seen in the outcomes of the analysis above, of having knowledge, skill and experience to be entrepreneurs. Though Chinese women were still less in numbers in 2010 than Chinese men in having enough self-efficacy in terms of their perception, but the gap in perception between genders reduced to $5.8 \%$ in 2010 compared to $21.8 \%$ in 2002 . Increasing number of women in 2010, were showing self-efficacy regarding their abilities through knowledge, skill and experience to establish business compared to men.

b. Would fear of failure would prevent you from starting a business?

Table4. Gender and the variable, Would fear of failure would prevent you from starting a business?

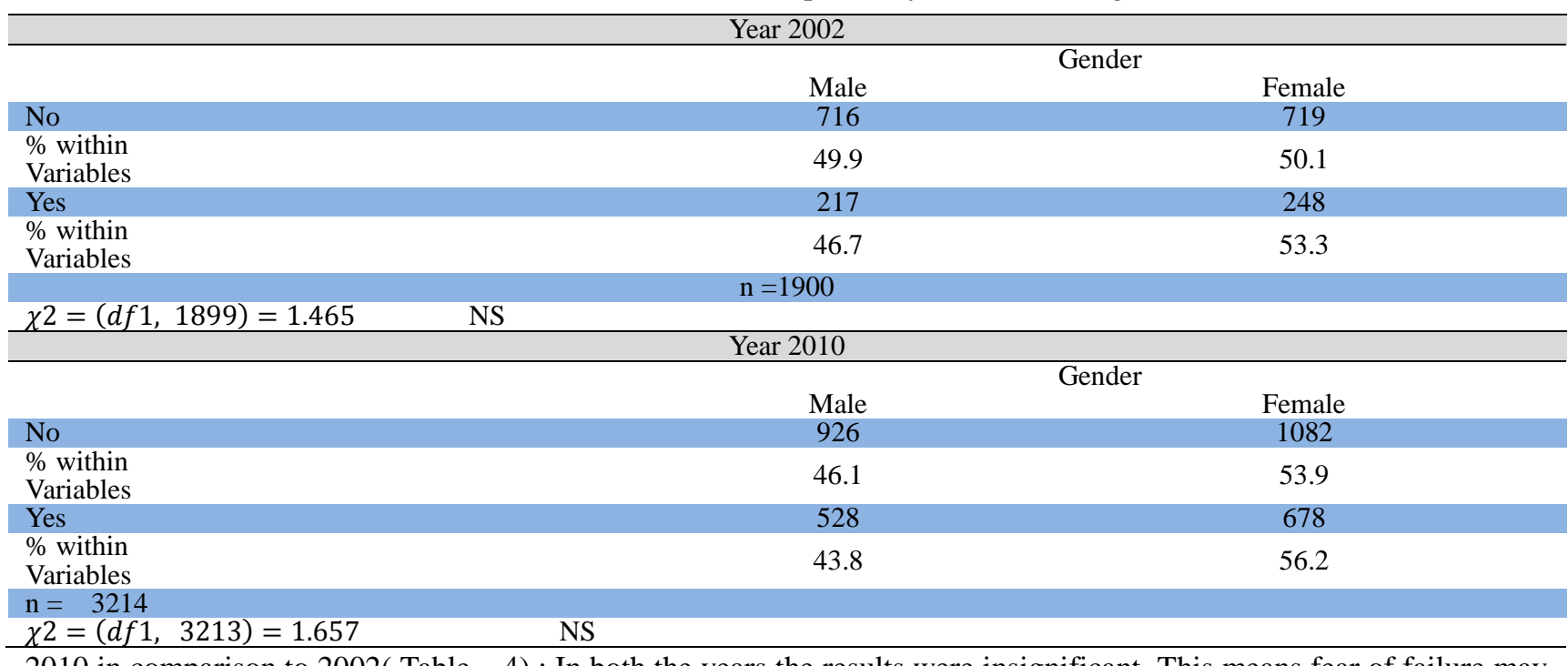

2010 in comparison to 2002 ( Table -4) : In both the years the results were insignificant. This means fear of failure may not vary across the genders. But perplexing fact in 2010 was , if we see the gap in women and men who denied that fear of failure was a factor to keep them off from starting business, had increased. This finding goes against the proposition, because the assumption was, with social and economic improvements, the gap should reduce. This may be because of large number of missing data or sampling error.

P2 : It is suggested that women in China were less involved in activities in past twelve months that would help to start a new business and they had less expectation than men to start a new business alone or with others, including any type of self-employment within the next three years, however these differences between genders would be expected to be narrower in 2010 than in 2002, due to socio-economy changes in China.

c. Over the past twelve months have you done anything to help start a new business?

Table5. Gender and the variable, Over the past twelve months have you done anything to help start a new business?

\begin{tabular}{|c|c|c|}
\hline \multicolumn{3}{|c|}{ Year 2002} \\
\hline & Male & Female \\
\hline No & 84 & 74 \\
\hline $\begin{array}{l}\% \text { within } \\
\text { Variables }\end{array}$ & 53.2 & 46.8 \\
\hline Yes & 116 & 64 \\
\hline $\begin{array}{l}\% \text { within } \\
\text { Variables }\end{array}$ & 64.4 & 35.6 \\
\hline $\begin{array}{l}\mathrm{n}=338 \\
\chi 2=(d f \\
* \mathrm{p}<0.05\end{array}$ & & \\
\hline \multicolumn{3}{|c|}{ Year 2010} \\
\hline & $\begin{array}{l}\text { Male } \\
265\end{array}$ & $\begin{array}{c}\text { Female } \\
256\end{array}$ \\
\hline $\begin{array}{l}\% \text { within } \\
\text { Variables }\end{array}$ & 50.9 & 49.1 \\
\hline
\end{tabular}




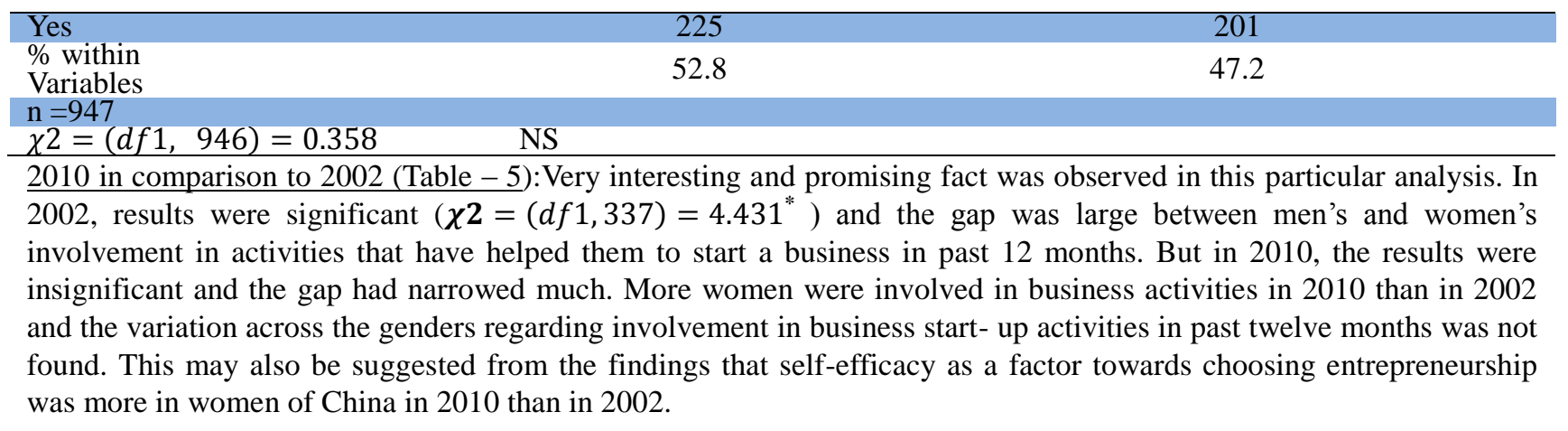

d. Are you, alone or with others, expecting to start a new business, including any type of self-employment, within the next three years?

Table6. Gender and the variable, Are you, alone or with others, expecting to start a new business, including any type of self-employment, within the next three years?

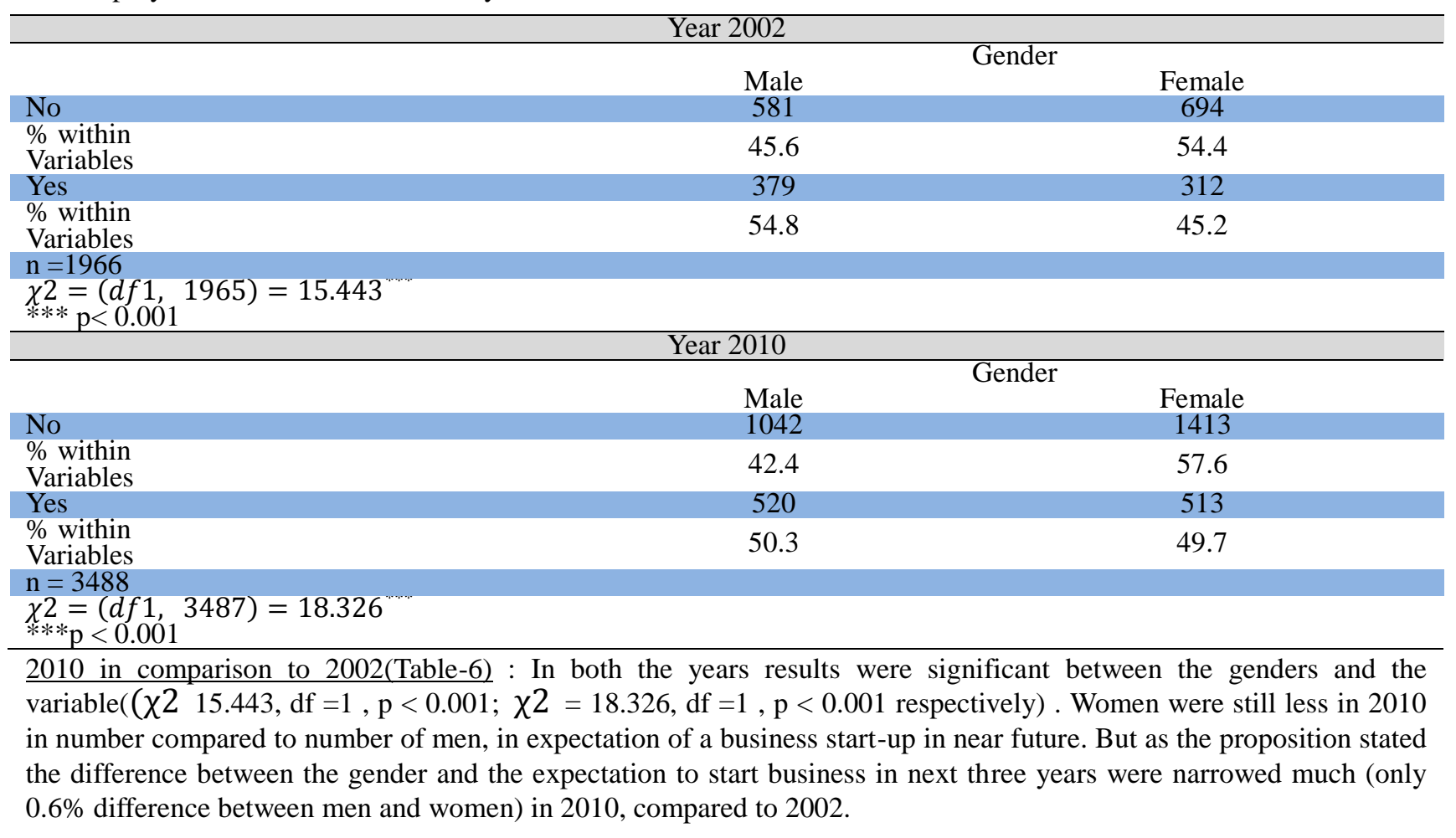

P3 : It is suggested that women in China would have less intention than men, in trying to start new business alone or with others, including any self-employment or selling any goods or services to others and therefore women would have less intention than men, of owning all, part or none of the business. Also, women in China should have less intention than in men, in trying to starting new business, or new venture for the employer as part of their normal work but however these differences in genders is expected to be narrower in 2010 than in 2002, due to socio-economy changes in China.

e. Are you, alone or with others, currently trying to start a new business, including any self-employment or selling any goods or services to others?

Table 7. Gender and the variable,Are you, alone or with others, currently trying to start a new business, including any self-employment or selling any goods or services to others?

\begin{tabular}{|c|c|c|}
\hline \multicolumn{3}{|c|}{ Year 2002} \\
\hline & \multicolumn{2}{|c|}{ Gender } \\
\hline & Male & Female \\
\hline No & 875 & 970 \\
\hline $\begin{array}{l}\% \text { within } \\
\text { Variables }\end{array}$ & 47.4 & 52.6 \\
\hline Yes & 119 & 81 \\
\hline
\end{tabular}




\begin{tabular}{|c|c|c|}
\hline $\begin{array}{l}\% \text { within } \\
\text { Variables }\end{array}$ & 59.5 & 40.5 \\
\hline \multicolumn{3}{|l|}{$\mathrm{n}=2045$} \\
\hline \multicolumn{3}{|c|}{$\begin{array}{l}\chi 2=(d f 1,2044)=10.531^{* * * *} \\
* * * \mathrm{p}<0.001\end{array}$} \\
\hline \multicolumn{3}{|c|}{ Year 2010} \\
\hline \multicolumn{3}{|c|}{ Gender } \\
\hline & Male & Female \\
\hline No & 1234 & 1637 \\
\hline $\begin{array}{l}\% \text { within } \\
\text { Variables }\end{array}$ & 43.0 & 57.0 \\
\hline Yes & 411 & 387 \\
\hline $\begin{array}{l}\% \text { within } \\
\text { Variables }\end{array}$ & 51.5 & 48.5 \\
\hline \multicolumn{3}{|l|}{$\mathrm{n}=3669$} \\
\hline \multicolumn{3}{|c|}{$\begin{array}{l}\chi 2=(d f 1, \quad 3668)=18.336^{* * * *} \\
* * * p<0.001\end{array}$} \\
\hline \multicolumn{3}{|c|}{$\begin{array}{l}2010 \text { in comparison to } 2002 \text { (Table } 7) \text { : Gender and the variable 'Are you, alone or with others, currently trying to start a } \\
\text { new business, including any self-employment or selling any goods or services to others? , when analysed for } \\
\text { association, it was found to be significant in both the years }(\chi 2=10.531, \mathrm{df}=1, \mathrm{p}<0.001 ; \chi 2=18.336, \mathrm{df}=1, \mathrm{p}< \\
0.001 \text { respectively). The outcome of the result matched the proposition. But the good thing is, the gap between women's } \\
\text { and men's intentions of starting new business was narrowed in } 2010 \text {. This means, women of China in } 2010 \text { showed } \\
\text { increase amount of career self-efficacy towards entrepreneurship and this may led in the increased intensions of } \\
\text { women in trying to start business at the time when survey was conducted compared to } 2002 \text {. In addition, the results in } \\
\text { both the periods were in line with the literature that career choice self-efficacy differs by genders in non-traditional } \\
\text { career choices, like, entrepreneurship. }\end{array}$} \\
\hline
\end{tabular}

f. Will you personally own all, part, or none of this business?

Table 8. Gender and the variable, Will you personally own all, part, or none of this business?

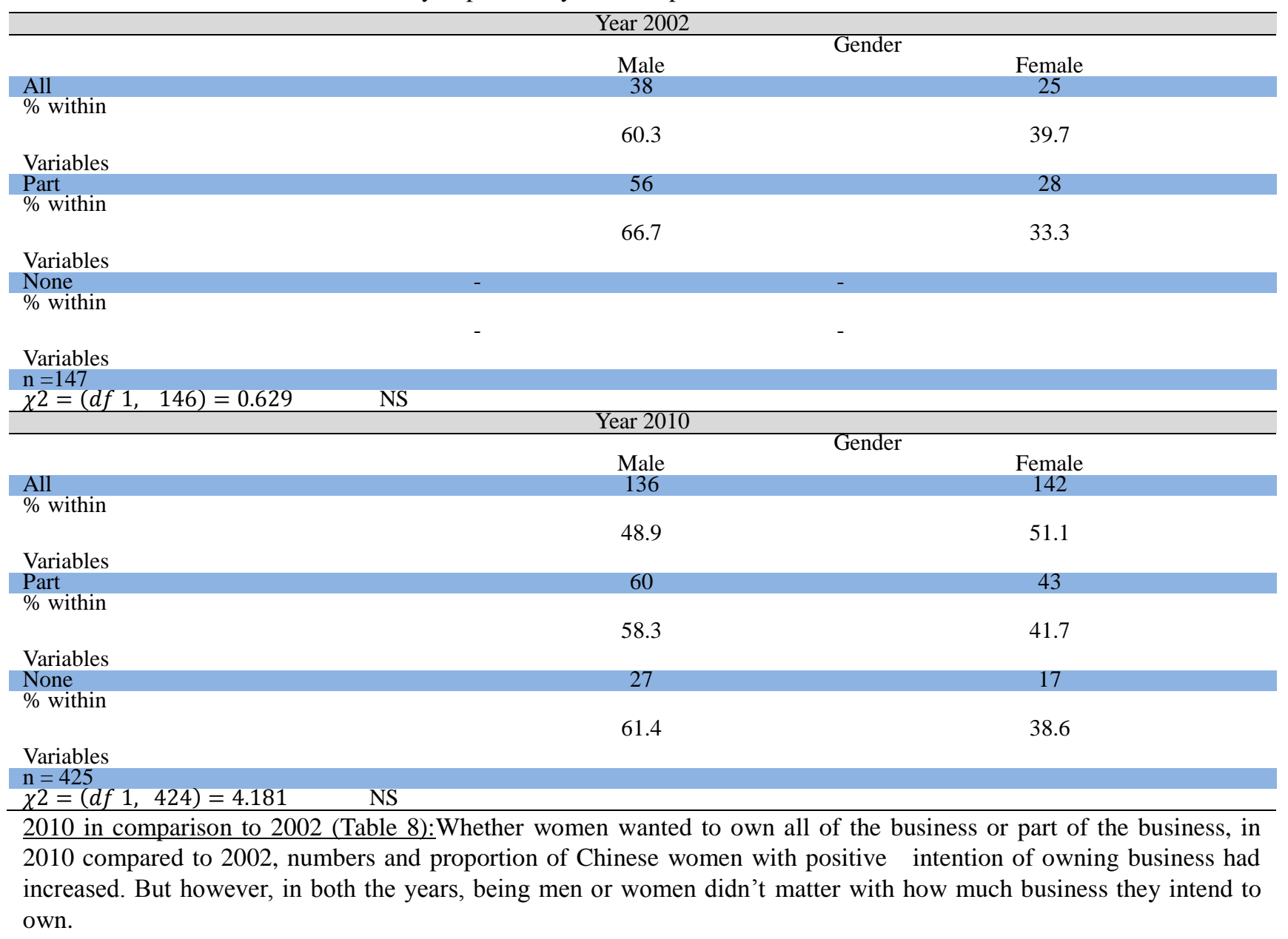

g. Are you, alone or with others, currently trying to start a new business or a new venture for your employer as 
part of your normal work?

Table 9. Gender and the variable,Are you, alone or with others, currently trying to start a new business or a new venture for your employer as part of your normal work?

\begin{tabular}{|c|c|c|}
\hline \multicolumn{3}{|c|}{ Year 2002} \\
\hline & & \\
\hline & Male & Female \\
\hline No & 901 & 993 \\
\hline $\begin{array}{l}\% \text { within } \\
\text { Variables }\end{array}$ & 47.6 & 52.4 \\
\hline Yes & 93 & 64 \\
\hline $\begin{array}{l}\% \text { within } \\
\text { Variables }\end{array}$ & 59.2 & 40.8 \\
\hline \multicolumn{3}{|l|}{$\mathrm{n}=2051$} \\
\hline \multicolumn{3}{|l|}{$\begin{array}{l}\chi 2=(d f 1, \quad 2050)=7.898^{*} \\
* \mathrm{p}<0.05\end{array}$} \\
\hline \multicolumn{3}{|c|}{ Year 2010} \\
\hline & Male & Female \\
\hline No & 1457 & 1883 \\
\hline $\begin{array}{l}\% \text { within } \\
\text { Variables }\end{array}$ & 43.6 & 56.4 \\
\hline Yes & 187 & 133 \\
\hline $\begin{array}{l}\% \text { within } \\
\text { Variables }\end{array}$ & 58.4 & 41.6 \\
\hline \multicolumn{3}{|l|}{$\begin{array}{l}\text { Variables } \\
\mathrm{n}=3660 \\
\chi 2=(d f 1,3659)=25.904 \\
* * * \mathrm{p}<0.001\end{array}$} \\
\hline \multicolumn{3}{|c|}{$\begin{array}{l}2010 \text { in comparison to } 2002 \text { (Table-9): The variation across the genders and the variable, 'Are you, alone or with others, } \\
\text { currently trying to start a new business or a new venture for your employer as part of your normal work?', were found } \\
\text { to be significant in both years }(\chi 2=7.898, \mathrm{df}=1, \mathrm{p}<0.05) \text {.In } 2010 \text {, as suggested by the proposition, that the difference } \\
\text { of women and men in trying to start entrepreneurial activities under the current employment reduced than what was in } \\
2002 \text {, but still the suggestion holds that Chinese women were less in number then their men counterparts but their career } \\
\text { self-efficacy towards entrepreneurship was better in } 2010 \text {. }\end{array}$} \\
\hline
\end{tabular}

\section{Discussion}

Overall summary of the results found in the data analysis showed that there were persuasive evidences that perceived desirability and intension towards entrepreneurship existed and varied among males and females in China, in 2002 and 2010. The study intended to make contributions regarding change in self-efficacy of women in China in becoming entrepreneur by doing a comparative study of two periods, 2002 and 2010.

First argument was based on the concept of 'self-efficacy' to explain whether women had self-confidence to be an entrepreneur through two factors, skill, experience, knowledge and fear of failure on the likelihood to engage in business start-up activity. This argument was developed by taking the gist of the studies done by Herron and Sapienza, (1992); Gist, (1987); Gist and Mitchell, (1992) ; Bandura, (1982); Boyd and Vozikis, (1994); Krueger and Brazeal, (1994). These authors suggested that self-efficacy was not biologically obtained but could be acquired by experience, learning, and social persuasion. The acquired skills, experiences, knowledge would in return strengthen one's self-efficacy. And negative factors, for example, lack of social persuasion, fear of failure, may weaken one's self- efficacy.

In both the years - 2002 and 2010, fewer women, compared to men perceived they had required knowledge, skill and experience to be an entrepreneur. This showed they have less confidence compared to males to be an entrepreneur. The finding of this part, also reflected the fact that, Chinese government's policies on the rights and equality between sexes had not been put to an end to traditional gender stereotypes regarding roles and duties within the family and society since the reform (Zheng,2010). Inequality, may never allow women in the society to grow their self-confidence even if they get proper education, knowledge and skill. They would perceive them inferior compare to their male counterparts. Because, in general belief, one's efficacy serves as a resource factor that act as buffer to neutralize distressing experiences fostering positive perceptions (Bandura, 1995). In contrast, individuals who are characterized by low perceived efficacy are prone to self-doubts, and anxiety (Bandura, 1995).The discussion on previous empirical findings of studies does reasonably said that individuals were more inclined to prefer a career choice as an entrepreneur if they had the confidenceto be successful based on the knowledge ,skills and experience they possessed and on their exposure to others who could help them providing useful knowledge (Boyd and Vozikis, 1994;Chen et al. 1998; Krueger and Brazeal, 1994). Moreover, this finding also supported arguments of Kourilsky and Walstad, (1998). They suggested and as discussed earlier, females tend to underestimate themselves even though both the genders may possess similar skills.

Self-Efficacy was also tested through respondents' fear of failure, in the years 2002 and 2010. Surprisingly, more 
females than males showed positive attitude towards failure, that is, they don't think fear of failure would prevent them from starting a business. Also, the variable 'fear of failure' didn't have significant association with genders. The outcome goes against the existing literature, for example - in a study done by Jianakoplos \& Bernasek(1998), showed that entrepreneurs as individuals deal with risky situations differently. There was some evidence that low risk tolerance was more visible in women than in men, like, in financial matters .Not only this, when women were asked about their attitudes, women reported a lower propensity toward risk than men (Johnson \& Powell, 1994) and appear to be more risk averse than men (Levin, et al. 1988). Scholars like Wagner, (2004), Johnson \& Powell, (1994)found that fear of failure could be an important factor that determined the difference in rate of new business creation between men and women. Johnson and Powell, (1994) explained the idea that women's low risk tolerance explains why there were low growth rates in female-owned companies. But in this study, result was against these literatures. This could possibly be explained in two folds. Firstly, the equal opportunity law and government supports in China made more females to be positive towards entrepreneurial thinking. Secondly, increased in gender pay gap in China, may led women to switch their career to be an entrepreneur, with a belief , that they would get more financial freedom. This phenomenon could be partially explained by the study ofMcMullen at al,.(2008),that opportunity-motivated entrepreneurial activity (OME) and necessity-motivated entrepreneurial activity (NME) was positively related to labour freedom. But further research is necessary in this area, in the context of China.

Second argument, was based on the concept of 'self-efficacy as a factor of career choice', to see whether women had more self-efficacy towards their career choice in 2010 than in 2002to get involved in entrepreneurial activities. From the study of Hollenbeck and Hall, (2004) as suggested, to demonstrate entrepreneurial intensions, behaviour self-efficacy belief was very crucial instead of their objective ability for having entrepreneur as a career. Belief of behaviour self-efficacy could be demonstrated by getting involved in activities that prepare the person for starting new business (Hollenbeck and Hall, 2004).

In 2002, less number of females compared to men showed any positive intentions of doing business, by getting involved in any activities that would help them to start a business. There was a gap of $28.8 \%$ between men and women in getting involved in activities in past twelve months thatwould help them to start a new business. And being involved in activities in past one year varied among genders. But when involvement in activities in past one year was checked in 2010, the difference between men and women was found to reduce to $5.6 \%$. Also, surprisingly genders didn't differ in their involvement in business activities in the past year.

The result of this part could be justified in two ways. Firstly, through the study of Bandura (1982) . He stated that people may develop a robust self-assurance that boosts self-efficacy as they continuously manage threats which led them to try hard to succeed. As Chinese women were continuously suppressed that may led them to try hard and gain self-confidence. Due to the movement of Chinese society towards liberalization, more women experienced less protection against discrimination, and became remote from the protection of the state as an employer, so probably women were forced to develop self-confidence in trying for a career of their own where they would find independence, like, entrepreneurship. Secondly, the finding may suggest an understanding of China's changing society. In midst of gender differentiation and stereotypes of Chinese women in the patriarchal society, percentage of women aged between (18-64) with no education had been significantly reduced (Attané,2012). In 2010, this fell to 6.6 percent in rural areas and to 3.5 percent in urban areas (Attané, 2012). Access to secondary and higher secondary education had tripled between 1990 and 2010 (Attané, 2012 ) . Education was a factor amongst other factors that improved women's status and also it changed the power relationship with men (Attané, 2012 ).

The findings of Attané, (2012)further supported the outcome of this study when intension of genders in expecting to start a new business, including any type of self-employment, within the nextthree years, was checked . This was also done to check 'self-efficacy as a factor of career choice'. In both the years 2002 and 2010 more number of males compared to females positively responded that they had intention to start a new business in next three years. But compared to 2002, in 2010 more females expressed intention to start a new business in next three years. Though, more males had intensions than females but the gap in the intentions of females' to be future entrepreneur than males' was much reduced . Moreover, future intensions to start new business varied among genders. Therefore, this portion of the analysis showed that though gender segregation existed in China in 2010, but gap in intention among genders had much narrowed. This result was similar to the literature discussed in this study, that males were more active in entrepreneurial activities than females and they had more confidence than females. In addition, since self-efficacy was one of the important and non-detachable element in the entrepreneurial intention model (Segal et al. 2005; Ajzen and Madden, 1986), one thing could be suggested from here that increase in female intentions to start business in 2010 reflected that Chinese females were growing more self-confidence to choose their career as entrepreneurs. More women getting education in 2010 (Attané, 2012)might have played important role in this.

Third argument, was based on the concept of 'career self-efficacy differs by gender' which would lead to explain 
self-efficacy differed by genders in traditional and non-traditional careers. This assumption was in line of the studies done by Lent and Hackett (1987); Nevill and Schleckler, (1988).

The findings for this part of the study was done in three folds. Firstly, by checking overall expectation among genders to choose entrepreneurship as careers at the time of the interview. In both the years ,2002 and 2010, women's expectation of starting a new business was less than men. But in 2010, gap had narrowed much in genders. It can be said that more females were expecting to be a self-employer in 2010. But since the association between expectation to be entrepreneurs and genders was found to be significant,so this result was in support of the literature regarding women entrepreneurs, and this was no different in China, that is , men were still leading in the entrepreneur career. This supported the work of Lent and Hackett, (1987) ; Nevill \& Schleckler ,(1988) that career choice was largely and significantly depended on self-efficacy and self-efficacy differed by genders in traditional and non-traditional careers. And since China had been a patriarchal and collectivism society, this part of the finding did show that though women had gained self-efficacy considerably in 2010 but couldn't outnumber their male counterparts.

Secondly, those who responded with positive expectation in the above portion were asked about their ownership of their intended business. This analysis helped to recognize people who were serious in their expectation of being an entrepreneur. From the results, it could be seen that what proportion of business people would be own was insignificant among genders. This was promising because intension of owing business did not vary in men and women, that more females were having the confidence to own all part or part of the business in 2010 compared to 2002.

Thridly, the study also examined that whether work-experience helped career choice and that in return increase self-efficacy among genders. Researchers have shown that the willingness of people to pursue entrepreneurial opportunities depends on their career experience (Carroll \& Mosakowski, 1987; Cooper, et al. 1989). Career experience can improve self- efficacy and may led managers/employees to be future entrepreneurs. This view was also supported by Blanchflower and Oswald, (1998) ; Taylor (1996), that among genders those who were employed individuals, were more likely to start a new business.

In 2010, increased number of women were trying to start a new business or a new venture for their employer as part of their normal work, than in 2002.Though the number of females were less than males but endeavour of women in initializing entrepreneurial activities with the present employment increased. Finding of this was another evidence that women were developing increased self-efficacy to show their capability to take risk to start new business for their employer. They may also have had high probability for future entrepreneurs but till 2010, it was a matter of future speculation. In addition, men and women varied in their endeavour to start a new venture for their employer. This did show there was segregation in self-efficacy among genders in China(i.e self-efficacy differs in genders) and this particular finding supported argument of Buttner and Rosen (1988), that, women had less risk-taking skills compared to men.

At the core of the existing literature on women's position in China, the assumption was that women were generally vulnerable with limited opportunities and resources, but in spite, fear of failure did not have any significant association with women to be entrepreneurs. It was further interesting to point to the results from the country-specific analyses that had been undertaken. Though women did not perceive to have enough skill, knowledge, experience but the overall results showed that more women had intentions to be future entrepreneurs in 2010, irrespective of what proportion of business they would own, no fear of failure could stop them and more women took participation in risk taking activities for their employers in their present job. Till 2010, this was also true, that women didn't outnumber men in entrepreneurial activities and their self-efficacy did differ from men but considerable improvements in their career choice as entrepreneurs were visible in this study.

\section{Acknowledgements}

My sincere gratitude to Prof. Carol Woodhams for guiding me throughout the paper. Also, I must thank Deanne \& Ray for proof reading the paper.

\section{Reference}

Attané, I. (2012). Being a Woman in China Today : A Demography of Gender. China Perspectives, 5-15.

Ajzen I, \& Madden, T. J. (1986). Prediction of goal-directed behavior: Attitudes, intentions, and perceived behavioural. Journal of Experimental Social Psychology, 22, 453-474.

Acs, Z., Arenius, P., Hay, M., \& Minniti, M. (2005). Global entrepreneurship monitor-executive report.London: London Business School and Babson Park, MA: Babson College.

Betz, N.,\& Hackett, G. (1981).The relationship of career-related self-efficacy expectations to perceived career options in college men and women. Journal ofCounselling Psychology, 28,399-410. 
Bandura, A. (1986). Social foundations of thought and action: A social cognitive theory. Englewood Cliis, NJ: Prentice-Hall

Bandura. A. (1977). Social learning theory. Englewood Cliffs, NJ: Prentice Hall.

Bandura, A. (1978). Reflections on self-efficacy. Advances in Behaviour Research and Therapy, 1, 237-269.

Bandura, A. (1995). Self-Efficacy in changing societies. Cambridge University press.

Bandura. A. (1982). Self-efficacy mechanism in human agency. American Psychologist, 7(2), 122-147.

Bandura, A., Barbaranelli, C., Caprara, G., \&Pastorelli, C. (2001) . Self-efficacy beliefs as shapers of children's aspirations and career trajectories. Child Development, 72(1), 187-206.

Boyd, N., \& Vozikis, G. (1994).The Influence of Self-Efficacy on the Development of Entrepreneurial Intentions and Actions. Entrepreneurship Theory and Practice, 18, 28-36.

Buttner, H., \& Rosen, B. (1988). Bank Loan Officers' Perceptions of the Characteristics OfMen, Women, and Successful Entrepreneurs.Journal of Business Venturing,3(3), 249-261.

Boyd, N. G., \& Vozikis, G. S. (1994).The Influences of Self-efficacy on the Development of Entrepreneurial Intentions and Actions. Entrepreneurial Theory and Practice, 18(4), 63-90.

Blanchflower, D.G., \& Oswald, A.J. (1998). What makes an entrepreneur? Journal of Labour Economics, 16(1), 26-60.

Cooke, F. (2003). Equal Opportunity? Women's managerial careers in governmental organisations in China. International Journal of Human Resource Management, 14(2), 317-333.

Cooke, F., \& Rowley, C. (2010).The Changing Face of Management in China. London: Routledge.

Carroll, G., \& Mosakowski, E. (1987).The career dynamics of self-employment. Administrative Science Quarterly, 32, $570-589$.

Chen, C., Greene, P., \& Crick, A. (1998). Does entrepreneurial self-efficacy distinguish entrepreneurs from managers? Journal of Business Venturing, 13, 295-316.

Cooper, A., Woo, C., \& Dunkleberg, W. (1989). Entrepreneurshipand the initial size of firms. Journal of Business Venturing, 3, 97-108.

Ebrey, P.B. (2003). Women and the Family in Chinese History, London: Routledge.

Eccles, J. (1994). Understanding women's educational and occupational choices. Psychology of Women Quarterly, 18, 585-609.

Estes, V. (1999).Women and business development: Promoting economic growth and job creation. USAID/Europe and Eurasia Bureau, Nov 8.

Gist. M. E. (1987). Self-efficacy: Implications for organizational behaviour and human resource management. Academy of Management Review, 12(3), 472-485.

Gist, M. E., \& Mitchell. T. R. (1992). Self-efficacy: A theoretical analysis of its determinants and malleability. Academy of Management Review, 17(2).

Granrose, C. S. (2007). Gender differences in career perceptions in the People's Republic of China. Career Development International, 12(1), 9-27.

Greene, C. K., \&Stitt-Gohdes, W. L. (1997).Factors that influence women's choices to work in the trades. Journal of Career Development, 23(4), 265-276. http://dx.doi.org/10.1177/089484539702300402

Hall.\&Christine, ( 1997). Daughters of the Dragon .Women's lives in contemporary China. Scarlet Press.

Ho, D.Y., \& Chiu, C.Y. (1994). Component ideas of individualism, collectivism, and social organization: An application in the study of Chinese culture. In U. Kim, H. Triandis, Ç.

Hackett, G., \& Betz, N. (1981). A self-efficacy approach to the career development of women. Journal of Vocational Behaviour, 18, 326-339.

Herron. L., \& Sapienza, H. J. (1992). The entrepreneur and the initiation of new venture launch activities Entrepreneurship Theory and Practice, 17(1), 49-55.

Hollenbeck, G., \& Hall, D. T. (2004). Self-confidence and leader performance. Organ.Dyn, 33(3), 254-269.

Jalbert, S. E. (2000). Women entrepreneurs in the global economy. Washington, DC: Center for International Private Enterprise. 
Jianakoplos, N. A., \& Bernasek, A. (1998). Are women more risk averse? Economic Inquiry, 36(4), 620-630.

Johnson, J. E.V., \& Powell, P. B. (1994). Decision making, risk and gender: Are managers different? British Journal of Management, 5(2), 123-138.

Kickul, J., \& D'Intino, R. (2004). Measure for measure: modeling entrepreneurial self-efficacy onto instrumental tasks within the new venture creation process. Presented at the United States Association for Small Business and Entrepreneurship Conference, Dallas, T. X.

Kim, H. \& Markus, H. R. (1999). Deviance or uniqueness, harmony or conformity? A cultural analysis. Journal of Personality and Social Psychology, 77(4), 785-800.

Kourilsky, M., \& Walstad, M. (1998). Entrepreneurship and female youth: Knowledge, attitudes, gender differences and educational practices. Journal of Business Venturing, 13, 77-88.

Krueger, N.F., \& Brazeal, D.V. (1994). Entrepreneurial potential and potential entrepreneurs. Entrepreneurship Theory \& Practice, 18(3), 91-104.

Kitching, B., \& Woldie, A. (2004). Female Entrepreneurs in Transitional Economies: a comparative study of Businesswomen in Nigeria and China. In Proceedings Hawaii International Conference on Business, Honolulu, Hawaii.

Kickul, J., W., F., \& Marlino, D. (2004). Are misalignments of perceptions and self-efficacy causing gender gaps in entrepreneurial intentions among our nations' teens? Presented at USASBE Annual Conference, Dallas, TX.

Kruskall, W., \& Mosteller, F. (1979).Representative Sampling, II: Scientific Literature,Excluding Statistics . International Statistical Review, 47, 111-127 . Longman Group Limited/Printed in Great Britain.

Losococo, K. A., \& Wang, X. (1992). Gender Segregation in China. Sociology and Social Research, 76(3), 118-26.

Lent, R. W., \& Hackett, G. (1987). Career self-efficacy: Empirical status and future directions. Journal of Vocational Behaviour, 30,347-382.

Leung, A.S.M. (2002). Gender and career experience in mainland Chinese state-owned enterprises. Personnel Review, 31(5), 602-619.

Liu, K, Dong X-y, \& Zheng, X. (2010). Parental Care and the Married Women's Labour Supply in Urban China, Feminist Economics, 16(3), 169-192.

Lu, D., \& Zhimin T. (1997). State Intervention and Business in China. Edward Elgar, Cheltenham.

Levin, I. P., Snyder, M. A., \& Chapman, D. P. (1988). The interaction of experiential and situational factors and gender in a simulated risky decision making task. Journal of Psychology, 122(2), 173-181..

Loscocco, K.A.,\&Bose, C.E. (1998).Gender and job satisfaction in urban China.The early post-Mao period. Social Science Quarterly, 79, 91-109

Maurer-Fazio, M., \&Hughes, J. ( 2002). The effects of market liberalization on the relative earnings of Chinese women. Journal of Comparative Economics, 30(4), 709-731.

McMullen, J., Bagby, D., \& Palich, L. (2008). Economic Freedom and the Motivation to Engage in Entrepreneurial Action. Entrepreneurship Theory and Practice, 32(5), 875-895.

Minniti, M., Arenius, P., \& Langowitz, N. (2005). Report on women and entrepreneurship. In Global entrepreneurship monitor. Wellesley, MA: The Center for Women's Leadership at Babson College.

McGee, J., \&Peterson,M. (2009). Entrepreneurial Self Efficacy : Refining the Measure. Entrepreneurship theory \&practice,33(4), 965 - 988.

Minniti, M. (2005).Entrepreneurship and network externalities. Journal of Economic Behavior and Organization, 57(1), $1-27$.

Nevill, D.,\& Schleckler, D. (1988).The relation of self-efficacy to willingness to engage in traditional/non-traditional career activities. Psychology of Women Quarterly, 12, 91-98.

Summerfield, G. (1994).Economic-Reform and the employment of Chinese women. Journal of Economic Issues,28(3), 715-732.

Scherer,R.,Adams.J., Carley, S., \& Wiebe. F. (1989). Role model performance effects on development of entrepreneurial career preference. Entrepreneurship Theory and Practice, 13(3), 53-81.

Scherer, R., Brodzinski, J., \& Wiebe, F. (1990). Entrepreneurial career selection and gender: A socializationapproach. 
Journal of Small Business Management, 28(2), 37.

Segal, G., Borgia, D., \&Schoenfeld, J. (2005). The motivation to become an entrepreneur. Int. J. Entrep. Behav. Res, $11(1), 42-57$.

Triandis, H.C. (1995). Individualism and Collectivism, Boulder, CO: Westview Press.

Taylor, M.P. (1996). Earnings, independence or unemployment; why become self-employed? Oxford Bulletin of Economics and Statistics, 58(2), 253-265.

UNIDO. (1995). Integration of Women in Industrial Development Unit, Participation of Women in Manufacturing: Patterns, Determinants and Future Trends, Regional Analysis, ECA Region, Final Report, Vienna.

UNIDO, (2001), Women Entrepreneurship Development in Selected African Countries. WorkingPaper, 7.

Wagner, J. (2004). What a difference a Y makes-Female and male nascent entrepreneurs in Germany (IZA DP No. 1134). IZAInstitute for the Study of Labor, Bonn, Germany.

Walby, S. (1989). Theorising Patriarchy. Sociology, 23(2), 213-234.

White, G., Howell, J. A., \& Shang, X. (1996). In Search of Civil Society: Market reform and social change in contemporary China. Oxford University Press.

Wood, R., \& Bandura. A. (1989). Social cognitive theory of organizational management. Academy of Managemenl Review, 14(3), 361-384.

Women-Owned Businesses. (2004). Washington, DC: The Center for Women's Business Research. XINHUA, December $16,2000$.

Yang, K. S. (1988). Will societal modernization eventually eliminate cross-cultural psychological differences? In M.H. Bond (Ed), the Cross-cultural Challenge to Social Psychology, 67-85. Newbury: Sage.

Yu, A.B., \& Yang, K.S. (1994).The nature of achievement motivation in collectivist societies. In U. Kim, H. Triandis, Ç. Kâğitçibaşi, S.C. Choi, \& G. Yoon (Eds), Individualism and Collectivism: Theory, Method, and Applications, 239250. London: Sage.

Zunker, V. (1994).Career counseling: Applied concepts of life planning (4th ed.). Pacific Grove, CA: Brooks/Cole.

Zheng,W. (2010).Gender, employment, and women's resistance, in Elizabeth J. Perry and Mark Selden (eds.), Chinese society: Change, conflict and resistance, London, Routledge, 162-186.

\section{(cc) $\mathrm{BY}$}

This work is licensed under a Creative Commons Attribution 3.0 License. 